\title{
In vitro efficacy of Beauveria bassiana (Balsamo) Vuill., Metarhizium anisopliae (Metsch.) Sorokin and Lecanicillium lecanii (Zimmerman) against Maconellicoccus hirsutus (Green) and Ferrisia virgata (Cockerell) (Hemiptera: Pseudococcidae)
}

RAJESH ILLATHUR* AND R. PHILIP SRIDHAR

Department of Agricultural Entomology, Tamil Nadu Agricultural University, COIMBATORE (T.N.) INDIA

\section{ARITCLE INFO}

Received : 07.05 .2016

Revised : 03.08.2016

Accepted : 17.08 .2016

KEY WORDS :

Beauveria bassiana, Pink mealy bug, Guava mealy bug, Spore, Mortality

*Corresponding author:

Email : rajeshreddy106@gmail.com

\begin{abstract}
Maconellicoccus hirsutus (Green) and Ferrisia virgata (Cockerell) were mass cultured in insectary using hibiscus plants, potato sprouts and the different stages were maintained to conduct bioassay. Entomopathogenic fungi Beauveria bassiana, Metarhizium anispoliae, Lecanicillium lecanii was sub-cultured on SDAY. Spore suspensions of concentration ( $1 \times 10^{8}$ conidia/ml) of seven isolates (BbBp1, BbGW1, BbBM1, MaBp1, $\mathrm{MaBm} 1, \mathrm{LlBm} 1, \mathrm{LlMo1})$ were prepared from the 15 day old culture of the fungi. A preliminary study on B. bassiana against Maconellicoccus hirsutus (Green) and Ferrisia virgata (Cockerell) female adults was done. untreated (sterile water) were used as controls. Mortality of pink mealy bug (Maconellicoccus hirsutus (Green)) adults under laboratory condition was recorded at different intervals where entomopathogens (\% mortality after $9^{\text {th }}$ day) like LlMo1 (93.33\%), BbGW1 (80.00\%) and MaBm1 $(63.33 \%)$. The mortality of guava mealy bug [Ferrisia virgata (Cockerell)] adults under laboratory condition was recorded at different intervals where entomopathogens (\% mortality after $9^{\text {th }}$ day) like LlMo1 (96.55\%), BbBp1 (86.21\%) and MaBp1 (65.52\%).

How to view point the article : Illathur, Rajesh and Sridhar, R. Philip (2016). In vitro efficacy of Beauveria bassiana (Balsamo) Vuill., Metarhizium anisopliae (Metsch.) Sorokin and Lecanicillium lecanii (Zimmerman) against Maconellicoccus hirsutus (Green) and Ferrisia virgata (Cockerell) (Hemiptera: Pseudococcidae). Internat. J. Plant Protec., 9(2) : 381-386, DOI : 10.15740/HAS/IJPP/9.2/381-386.
\end{abstract}

